\title{
Critical Analyses of Pak-Afghan Transit Trade Agreement: Pakistan's Perspective
}

\author{
* Rooh Ul Amin, PhD Scholar (Corresponding Author) \\ ** Dr. Ghulam Muhammad Awan, PhD \\ *** Dr. Faryal Raheem
}

\begin{abstract}
Asia's Cockpit, Afghanistan, is not only a strategic neigbour but also share intellectual, geographical, cultural, and diplomatic relations with Pakistan. Pakistan and Afghanistan's long but porous border has been a source of trade, people interaction, and economic integration. The landlocked Afghanistan seeks an opportunity for trade through Pakistan under the provision of GATT Article V, UN law of Seas 1981 and New York Convention-1965. This study is conducted to examine Pak-Afghan Transit Trade relations over the years. Study is descriptive in nature based on data extracted from published government sources and research papers. Study found that Pak-Afghan signed two transit trade agreements i.e. Afghan Transit Trade Agreement on March 02, 1965 at Kabul and Afghan-Pak Transit Trade Agreement on October 28, 2010 at Islamabad. Under this agreement Pakistan permitted using of territory for trade transit enter from Karachi Port and Port Qasim and exist through Chaman and Torkham. Study found these agreements are bilaterally beneficial, however the research revealed that volume of Afghan transit trade decreased due to the sporadic events of border closures over the years and resultantly Afghanistan seeks transit trade opportunities through Turkmenistan, Iran, Uzbekistan and Tajikistan as per mutually agreed transit trade agreements with them. Afghan's transit trade shift through other routes has serious implications for Pakistan sociopolitical and socio-economic interests. Since, peace and prosperity passes through international trade and economic integration therefore, both countries should adopt realistic approach towards each other's sensitivities and concerns. Afghanistan must take a serious measures in controlling flow of smuggling and terrorism across Afghan land to Pakistan. The research recommends revisiting of the agreement and realign with the obvious opportunities emerging from the CPEC. Afghan should permit and facilitate Pakistan to trade with Central Asia and beyond using Afghan territory. The research further recommends that both countries to ensure that their bilateral relation are not affected by ties with any other country.
\end{abstract}

Keywords: $\quad$ Pak-Afghan Relation, Transit Trade, Afghan Transit Trade Agreement, AfghanistanIntroduction

Pakistan Transit Trade Agreement.

Afghanistan's "Asia cockpit" is not only strategic but also intellectually, geographically, culturally, and political neighbors of Pakistan (Khawar, 2005). History revealed that invaders, investor, and tourists visited the Indian subcontinent from Afghanistan through Khyber Pass, Sindh, and crossing Punjab to reach Delhi and beyond (Naqvi, 2012). History revealed an ongoing process of communication between the peoples of Afghanistan and the subcontinent. However, after division Pakistan and India have established and maintained relations with Afghanistan as per respective state interests. By Implication, Pakistan has more similarities with Afghanistan however owing to the informal conflicts, crests, and troughs in its relationships it is deemed acceptable. Owing to immense similarities this warmth relation has often weakened the horrible taste drastically. The development of strategic relations between the two countries mainly dependents on a long-distance shared border of more than 2,500 kilometers, which is crossing every day by numbers of people, and a useful source of people interaction, trade, and economic integration (Haider \& Irfan 2015). Therefore, the power to facilitate a stable union is powerful. Moreover, this mutual trust and relation are supported by the

* Department of Peace \& Conflict Studies, National Defense University (NDU), Islamabad, Pakistan

Email: rua58@yahoo.com

** Department of Peace \& Conflict Studies, National Defense University (NDU), Islamabad, Pakistan

Email: sizova79@ hotmail.com

*** Abasyn University Peshawer Email: faryal.raheem@abasyn.edu.pk 
nature of the importance of dualism between the two countries, as the stability of one country straight affects the internal steadiness of the other country (Irshad, 2011). The origins of this relation are held back to the era before the partition of the subcontinent. The relation, by and large, persisted public after the partition of the continent, despite explosions and continued outrageous outrages, psychological and social skepticism, and conflicts of interest on a number of issues at the state level (Yousufzai, 2017).

Considering the geographical location, Pakistan and Afghanistan are contemporarily affected by international and regional activities and fluidity of global reform. When the USSR invaded Afghanistan, there was a government supporting the USSR and the anti-Pakistan in Kabul, yet Pakistan opened its arms and accommodated more than three million Afghan refugees. Although the US-led invasion of Afghanistan and the lingering existence of foreign forces have caused a great deal of controversy in Pak-Afghan relations, but both continued man-to-man connection, mutual help, and local networking have prevented several serious issues at all level. Pakistan and Afghanistan are successfully maintaining good cultural, political, and strategic ties over the years (Imtiaz, 2012). Besides, the need of socio-political stability amongst the neighbors, Pakistan's melting down of economy also needs booming trade between the two not only in formal sector (Baloch, 2009; Baloch et. al., 2020) but its regional integration through tourism as well (Baloch \& Rehman 2015). However, no research study has conducted to comprehensively examine Pak-Afghan transit trade relations over the years.

\section{Research Question:}

This study aims to evaluate the currently operative Afghanistan-Pakistan transit trade agreement with a view to identify grey areas affecting Pakistan's socio-economic interests and suggest measures for its improvement for the benefits of both countries in longer run.

\section{Research Objectives:}

The following research objectives were set for this study:

a. To describe the evolving history of Pak-Afghan transit trade relations experienced over the years.

b. To critically examine the salient features of various transit trade agreements arranged between Pakistan and Afghanistan.

c. To ascertain the current status of trade and put forward recommendations based on study findings in order to improve the trade prospects.

\section{Pak-Afghan Transit Trade Relation}

According to International law, Pakistan obligates to provide trade and transit facilities to land-locked Afghanistan. Despite numerous conflicts between the Pakistan and Afghanistan relations and consequently trade and transit relation between the countries has been occasionally suspended over the years (Haque 2011). The transport agreement benefited Afghan goods and also provided an opportunity for Pakhtuns on both sides of the Durand line rental and livelihoods. In Pakistan Federal Administrated Tribal Areas (FATA) and Afghan border areas are very difficult region due to excessive mountains, small desert valleys, and rocks (Umar, 2009). About $80 \%$ of the area is unfertile and extremely hard to cultivate (Choudary, 2004). Afghanistan seizes the opportunity to trade in the port of Karachi. In 1961, in the era of Prime Minister Daud's border crossing situation worsened and both countries have closed the border crossing, which has greatly affected the trade activities in Afghanistan (Kiani, 2010). However, in 1963 Shah of Iran assisted in a truce between Pakistan and Afghanistan. The Pakistan president Ayub Khan desired to address Pak-Afghan trade and transit disputes through talks in this regard he visited Afghanistan in 1964 and 1966 repeatedly. In order to keep Pak-Afghan relations stable just after the 1962 border closure issue, Pakistan has agreed on providing a trade corridor to Afghanistan (Mahmoud, 2013). In this regard, the Afghan and Pakistan governments have mutually signed a trade and transit agreement on March 02, 1965, at Kabul socalled Afghan Transit Trade Agreement (ATTA) (Choudary, 2004). According to Yousaf (2012), the landlocked Afghanistan needs a permanent trade route and Pakistan obligates to provide trade access to Afghanistan in accordance with international rules Article V of GATT to facilitate the landlocked countries for trade also supported by UN law of Seas 1981 (United Nations, n.d). Under this provision, Pakistan has provided more trading opportunities to Afghanistan through Pakistan with India and CARs oil and gas-rich countries. Both countries are currently enjoying more than two billion dollars trading and 34\% of Afghan goods pass through the Pakistani border (Abbasi, 2011). 
ATTA was in practice from 1965 to 2010, however, due to urgency the outdated ATTA was found no more effective and suspended accordingly. In the face of new developments of systematic improvement and the emerging of new hitches in Pak-Afghan relation and monitoring as well as normalization of trade power has diverged both states to establish a neoteric transit agreement (Nuri, 2012). Removing trade barriers, to strengthen economic ties also ensure free shipping and improve mutually coordination a joint group was nominated for evaluation of cost and benefits of this new agreement. In this regard, a series of negotiations were started from 2006 followed by 2008 and 2009. After careful consideration, a Memorandum of Understanding (MoU) was signed between Pakistan and Afghanistan on 6 May 2009 by the both states commerce ministers in the presence of Hillary Clinton US state secretary, Hamid Karzai Afghan president and Asif Ali Zardari President of Pakistan (Afzal 2010). Considering the point of previous trade agreement ATTA of 1965 limitations both countries have focused with aimed to address each other's deliberations in a positive way. For this purpose, various meetings between the countries were held periodically. Also, recommendations and suggestions were called from all stakeholders and main concern of Pakistan was revealed the smuggling of commodities in the form of transit trade and this issue was likely to be addressed in the new transit treaty (Pakistan Observer, 2012). In order to address similar concerns finally, this strategic agreement was signed between the two countries on 28 October 2010 at Islamabad. The treaty has signed by Pakistan finance minister Dr. Abdul Hafeez Sheikh and counterpart Hazrat Umar Zakhilwal Afghanistan finance minister. The treaty becomes operational with effect from 21 June 2011 (Syed, 2013). Under this treaty both the states also mutually agreed on the provision of permit to Afghan trucks through Karachi and Wagha border to transit Afghan goods to India and beyond (Syed, 2013).

\section{Pak-Afghan Transit Trade Framework}

The General Agreement on Tariffs and Trade is the legal agreement to minimize international trade barriers also reduce or eliminate tariffs, quotas and subsidies in order to provide significant regulations. This agreement was initially signed by 23 countries on 30 October 1947 and implemented with effect from 01 January 1948. Pakistan became a member of the General Agreement on Tariffs and Trade since 30 July 1948. Article V of this agreement and the New York Convention regarding Transit Trade of Landlocked countries-1965 have obligate Pakistan to provide transit facilities to landlocked Afghanistan (Siddique, 2011). Under this provision, Pakistan and Afghanistan mutually signed the following two agreements in order to maintain a good transit trade relationship (Gartenstein, 2012).

a. Afghan Transit Trade Agreement (ATTA)

b. Afghanistan Pakistan Transit Trade Agreement (APTTA)

Afghan Transit Trade Agreement (ATTA)

Pakistan obligates to provide trade transit facilities to landlocked Afghanistan under the provision of GATT Article V, UN law of Seas 1981 and New York Convention-1965. According to Choudary, (2004) Pak-Afghan governments have mutually signed a transit trade agreement on March 02, 1965, at Kabul so-called Afghan Transit Trade Agreement (ATTA). This agreement comprised 15 articles and two annexes deals with transit routes, transport and customs procedure (Abbasi, 2011). Under this agreement Pakistan allowed using of territory for trade transit enter from Karachi Port and Port Qasim and exist through Chaman and Torkham. The trade routes and track in Pakistan as well as Afghanistan were no specified under this agreement. Moreover, according to this agreement Afghan Transit Trucks were not allowed to enter Pakistan however, transportation facilities inside Pakistan was initial provided by Pakistan Railway and later on Pakistan National Logistic Cell (Sarhadi, 2013). Under this agreement both countries are bond to facilitate each other with regard to transit trade irrespective of ownership of transport or goods, its origin and vessel flag and/or its exit/entrance point. The official language of ATTA was both English and Dari. This agreement was ratified to be renewed with interval of five years. Moreover, no political stand or disagreement will suspend or affect ATTS in coming years (Sarhadi, 2013). If any issue arises the member countries resolved through dialogs or approach to third party based on consensus. Both countries meet and discuss the progress of the agreement once a year, also deploy liaison officers to monitor the progress of transit under ATTS and resolve transit trade issues at the spot (if any). This agreement ensured the protection of public, animals and plants lives as well as heath and protect measures are required to safeguard each other. Furthermore, Pakistan provide open spaces and sheds at Karachi Port to Afghanistan for transit goods and all goods, commodities and baggage's must be counted transit. This agreement stipulates that 
both countries relaxed port duties and freight charges and no provincial or national taxes and/or custom are to be charged on goods transit expect administrative, transportation and cost of services charges (Haider, 2015).

\section{Afghanistan- Pakistan Transit Trade Agreement (APTTA-2010)}

The onset instability in Afghanistan's aftermath of 9/11 accident has drastically changed the regional stability and transit trade dynamics. This regional changed beside with dissolution of Soviet Union has provided opportunities to Pakistan for reviving its strategic ambition regarding access to Central Asian Republics (CAR). Whereas, Afghanistan also striving for reconstruction with international community support through inevitable hefty imports and impending to enhance Afghanistan exports. This changings have opened gateways for CARs to interact with global as well as regional markets with greater regional amalgamation. Pakistan and Afghanistan acknowledged the dire needs to evaluate and review the existing transit agreement. In this regard, a series of negotiations were started from 2006 followed by 2008 and 2009. The new agreement draft was prepared by World Bank on the bases of World Customs Organization Revised Kyoto Convention (Federal Board of Revenue, 2011). The new treaty drat was presented by Kabul to Islamabad and after careful consideration, a Memorandum of Understanding (MoU) was signed between Pakistan and Afghanistan on 6 May 2009 duly signed by states commerce ministers in the presence of Hillary Clinton US state secretary, Hamid Karzai Afghan president and Asif Ali Zardari President of Pakistan (Afzal 2010). AfghanistanPakistan Transit Trade Agreement (APTTA) strategic treaty was signed by finance ministers of both countries on 28 October 2010 at Islamabad. The treaty becomes operational with effect from 21 June 2011 (Syed, 2013). Under this treaty both the states also mutually agreed on the provision of permit to Afghan trucks through Karachi and Wagha border to transit Afghan goods to India and beyond (Syed, 2013).

The new treaty is initially effective for five years and after expiry of five years or as and when required before completion of five years this agreement will be renowned through mutual consideration (Nuri 2012). Pak-Afghan Transit Trade Coordination Authority was established to tackles the issues/disputes related to transit trade. APTTA open trade horizons for both states by providing ten additional transit flight paths and eight corridors in Pakistan and Afghanistan respectively (Afghanistan 2010). According to APTTA both states must facilitate transportation of goods in their respective regions also provide freely transportation of goods on selected routes. Moreover, under this agreement each country must provide specific transit routes by sea, air, land and train combine with provision of international standard services and infrastructure for transit trade. For road cargo Pak-Afghan governments were agreed to recognize and accept the transit trade carrier documents such as driving license, vehicles inspection certificate and registration also other technical documents like entry and exit permits etc. According to international custom rules both countries are bound to facilitate fast delivery of fragile goods and exclusively halted the transportation of narcotic drugs and arms (Abbasi,, 2011). For this purpose cargo may be checked at any point if any irregularity is suspected according to RKC-1999. Pakistan major concerns is about smuggling in form of transit trade and first time in the history Afghanistan acknowledge and recognized the adverse impact of smuggling on socio-economic development of a country. APTTA addressed the issue of smuggling through remedy measures like installation of tracking devices in the transit carries, all containers will be sealed and only financial taxes guaranteed sealed cargo will be allowed. Pakistan established container scanner to facilitate the custom officials to examine the goods in the containers without opening (Abbasi, 2011). This agreement obligates Pakistan to provide transportation access to Pakistan through road and rail from Karachi/Qasim Port via Peshawar further proceed to Torkham. The second destination of trade transit starts from Karachi/Qasim Port via via Chaman or North Waziristan Ghulam Khan to Afghanistan.

\section{Critical Analysis of the Agreement}

Since first day Pak-Afghan trade alliance has received a remarkable growth and achievements over the year. The below table depict the share of afghan transit trade over the year starting from 2006 to 2018 through Pakistan. Table show that in 2005 Afghan transit trade share through Pakistan was 28\%, followed by $30 \%$ in 2006, $21 \%$ in 2007 and reduced to recorded level only 19\% in 2008, 33\% in 2009 and the highest in 2010 i.e. $60 \%$ in the era of ATTA. In late 2011 APTTA was implemented, however, transit trade was conducted under ATTA till the implementation of APTTA and share was recorded $22 \%$, followed by $24 \%$ in $2012,42 \%$ in $2013,58 \%$, in $2014,54 \%$ in $2015,55 \%$ in 2016 , 
59\% in 2017 and 52\% in 2018. These statistics revealed that under APTTA the highest transit trade was recorded in 2017, whereas, the lowest was noticed in 2012 only 24\%, clearly indicates that just after implementation of APTTA Afghan transit trade share was decline in subsequent year. The causes may be term and condition of the APTTA or the worst Pakistan law and order situation and/or Pakistan deteriorating relation with NATO/US due to Abbottabad and Salala incidents (Samir \& Attarwala, 2015).

\section{Afghan Transit Trade Agreement (ATTA-1965)}

Pak-Afghan transit trade under ATTA-1965 was witnessed increased and Afghanistan exports through Karachi/Qasim port and land route of Wahga to India was also part of this bilateral trade agreement included and become effective since 1980. Whereas, Afghanistan received imports only through Karachi/Qasim port of Pakistan. The below figure reflect the Afghanistan export through Pakistan under ATTA. The following figure show that Afghanistan export was recorded highest in 2006 i.e. 80million US\$ and lowest in the year 2009 only 40million US\$. The figure also show the import of Afghanistan through Pakistan was crossed 1billionUS\$ in 2009 from 475millionUS\$ in 2005. The cause may be support of international community in rebuilding/reconstruction of Afghanistan after terror war.

\begin{tabular}{lllll}
\hline Year & Exports & Imports & Trade Turnover & Balance \\
\hline $\mathbf{2 0 0 5 - 2 0 0 6}$ & 1063.4 & 47.5 & 1110.9 & 1015.9 \\
$\mathbf{2 0 0 6 - 2 0 0 7}$ & 753.9 & 76.2 & 830.1 & 677.7 \\
$\mathbf{2 0 0 7 - 2 0 0 8}$ & 1143.6 & 91.3 & 1234.9 & 1052.3 \\
$\mathbf{2 0 0 8 - 2 0 0 9}$ & 1398.0 & 93.0 & 1491.0 & 1305.0 \\
$\mathbf{2 0 0 9 - 2 0 1 0}$ & 1572.0 & 139.0 & 1711.0 & 1433.0 \\
$\mathbf{2 0 1 0 - 2 0 1 1}$ & 2336.7 & 172.0 & 2508.7 & 2164.7 \\
\hline
\end{tabular}

Pak-Afghan trade from 2005-2011 (US\$ million)

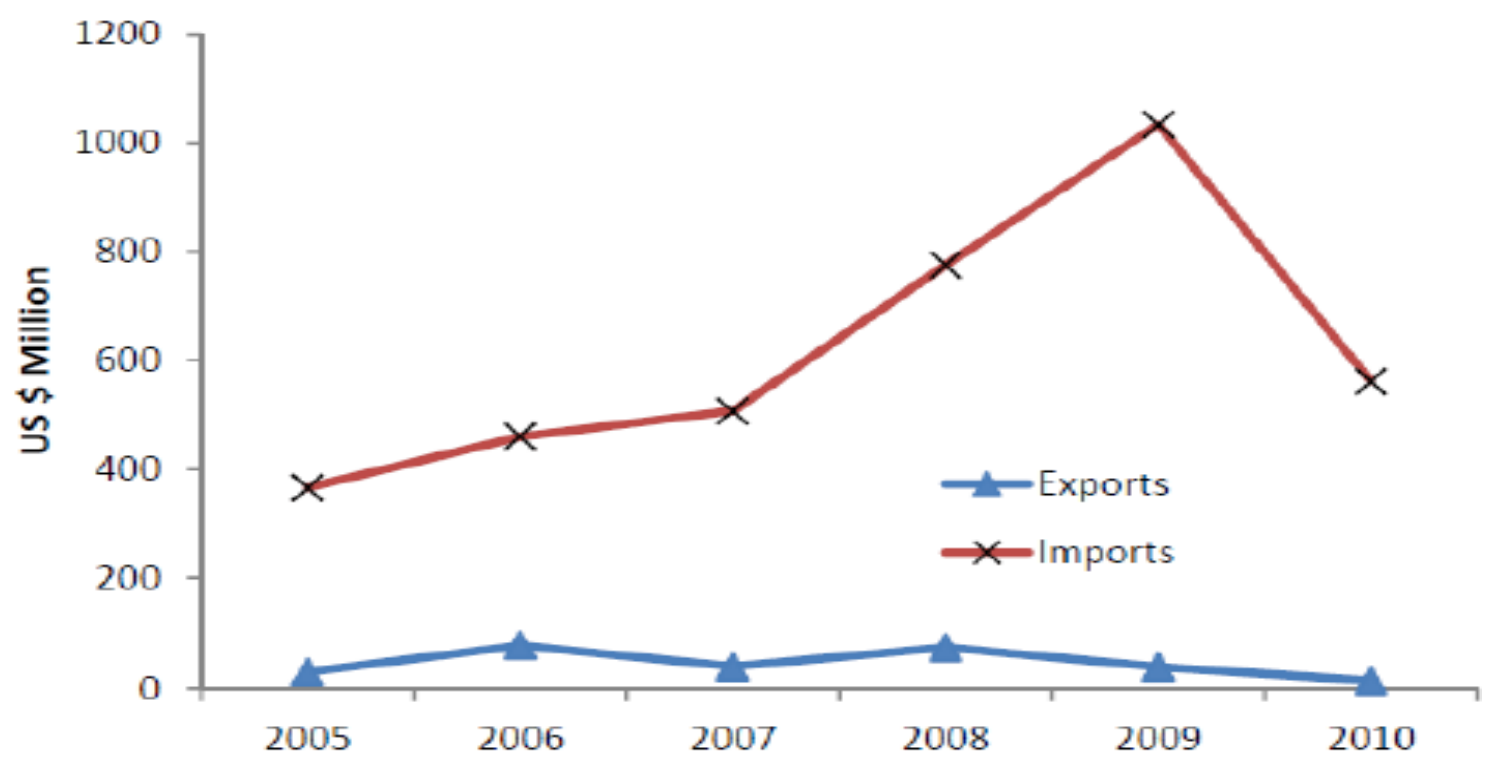

Afghanistan Pakistan Transit Trade Agreement (APTTA-2010)

Pak Afghan transit trade under APTTA-2010 emerged in the face development and suspension of ATTA-1965. This agreement was noticed initially decrease in transit trade however, it was recorded increased over the years. Afghanistan was allowed to import/exports through Karachi/Qasim port by sea, air and land routes such as Ghulam Khan and Wahga to India. The below table reflect the Afghanistan transit trade through Pakistan under APTTA. The statistics show that Afghanistan total export in 2011 was recorded 375million US\$ and 48\% Pakistan share similarly import was 6390 with Pakistan 13.7\%. Followed by 2012 Afghanistan total export was 428 with $46 \%$ Pakistan share and import 6204 with 14.2\% Pakistan share. In 2013 Afghanistan total export was 514 with 38\% Pakistan share and import 8554 with $10.3 \%$ Pakistan share. In 2014 Afghanistan total export was 570 with 33\% Pakistan share and import 7697 with 14.2\% Pakistan share. In 2015 Afghanistan total export was 571 with 39\% Pakistan share and import 7722 with 17.4\% Pakistan share. In 2016 Afghanistan total export was 596 with 47\% Pakistan share and import 6534 with 18.3\% Pakistan share. In 2018 


\begin{tabular}{lllllll}
\hline \multirow{2}{*}{ Year } & $\begin{array}{l}\text { Exports } \\
\text { World }\end{array}$ & $\begin{array}{l}\text { Pakistan } \\
\text { (US\$M) }\end{array}$ & $\begin{array}{l}\text { Imports } \\
\text { World } \\
\text { (US\$M) }\end{array}$ & $\begin{array}{l}\text { Pakistan } \\
\text { (US\$M) }\end{array}$ & $\begin{array}{l}\text { Trade Turnover } \\
\text { World }\end{array}$ & $\begin{array}{l}\text { Pakistan } \\
\text { (US\$M) }\end{array}$ \\
\hline $2011-2012$ & 375 & $180(48 \%)$ & 6390 & $877(13.7 \%)$ & 6765 & 1057 \\
$2012-2013$ & 428 & $201(46 \%)$ & 6204 & $883(14.2 \%)$ & 6632 & 1084 \\
$2013-2014$ & 514 & $198(38 \%)$ & 8554 & $889(10.3 \%)$ & 9068 & 1087 \\
$2014-2015$ & 570 & $188(33 \%)$ & 7697 & $1320(17.2 \%)$ & 8267 & 1508 \\
$2015-2016$ & 571 & $226(39 \%)$ & 7722 & $1340(17.4 \%)$ & 8318 & 1566 \\
$2016-2017$ & 596 & $283(47 \%)$ & 6534 & $1190(18.3 \%)$ & 7130 & 1473 \\
2018 & 884 & $379(42 \%)$ & 7604 & $1080(14.6 \%)$ & 8488 & 1459 \\
\hline
\end{tabular}

Afghanistan total export was 884 with $42 \%$ Pakistan share and import 7604 with $14.6 \%$ Pakistan share.

Pak-Afghan trade from 2011-2018 (US\$ million)

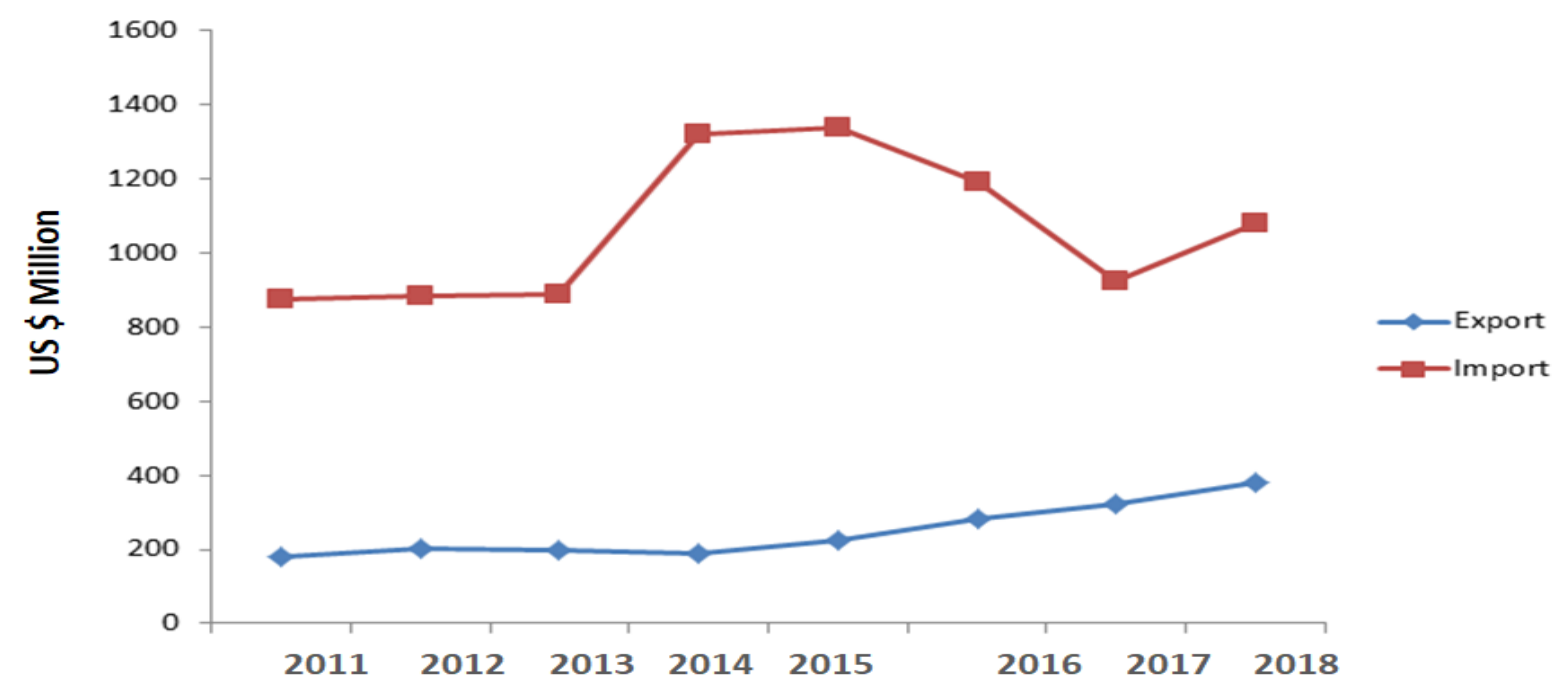

The above statistic revealed that Afghan transit trade was decreased due to sudden prolonged boarder closure like in 2015 about 52,000 tons pomegranates were exported UAE and India through Pakistan however, the same was reduced to 15,000 along with other fruits and vegetables in 2016 due to boarder closure, similarly in 2017 Pak-Afghan transit trade was suspended and about 3500 trucks were remained stranded in each side due to boarder closure (The Dawn, 2017). Moreover, Afghanistan not only trade transit through Pakistan but also singed transit agreements with Turkmenistan, Iran, Uzbekistan and Tajikistan. Despite, Afghanistan preferred transit trade with Pakistan but adopt other option due to impoverished trade relation.

Salient Implications of APTTA-2010: The new agreement of transit trade has following salient implications:

a. The agreement provides a dispute settlement committee for the resolution of any issue emerged between both parties under the name of Pak-Afghan Transit Trade Coordination Authority (PATTA).

b. An informal trade between the both trade partners has scaled to $\$ 4$ billion. The new Transit trade agreement offers lots of leverage and prize of a captive market to the regional trade partners particularly for Pakistani goods.

c. Pakistan traded its goods worth valuing $\$ 1.2$ billion in 2012 as compared to $\$ 1.7$ billion in 2011. The reduction in trade volume after 2014 is mainly due to the substantial withdrawal of international security forces including American troops from Afghanistan.

d. Afghanistan's lucrative minerals deposits have attracted many countries and around hundreds of Indian business concerns have invested in Afghanistan's infrastructure to tape benefits from these mineral deposits. (Price, 2013)

e. The APTA -2010 transit trade agreement displaces the ATTA of 1965 which did not offer Pakistan reciprocal rights to export goods through Afghan's soil to Central Asia or Soviet Union. 
f. The ATTA-1965 could not control the smuggling back of the imported goods in Pakistan via its porous border or prematurely offloading of Afghanistan's bound goods within Pakistani territories and flooding Pakistani markets with duty free goods. This all helped in thriving of black market in Pakistan and a huge loss to Pakistan tax revenue.

g. Pakistan's stringent control measures in preventing smuggling or premature offloading of Afghanistan destined goods resulted in re-routing of Afghan trade via Iran thereby resulting in to an abrupt cuts of smuggled goods in Pakistani markets on one hand, and decline in Pakistan's tax collection and jobs related to Afghan trade.

h. The APTTA permits use of both trade partner's seaports, airports, rail and road network along specific transit corridors however, it doesn't allow use of transport from third country- from Central Asia or India.

i. The specified border crossing to Pakistan for Afghan trucks include; Chamman, Torkham, and Ghulam Khan; and Pakistani ports to be used for import of goods are Karachi, Port Qasim and Gwadar. However, the Agreement also allows Afghanistan trucks to off load their exported goods at Indian Wagah border with India but not allowed import of Indian goods across Pakistani territory in order to prevent creation of a black market for Indian goods in Pakistan (Baloch, 2008).

j. The APTTA assures control measures to prevent smuggling of duty-free goods into both Pakistan by authorizing: use of tracking devices, banking guarantees, special licenses for transit trade carrier trucks, and container security deposits etc.

k. The ATTA-1965 did not provide Pakistan with the mutually reciprocal rights of exporting its goods across Afghan soil to Central Asia and other neighboring countries. Pakistani's trade access the Central Asian markets was facilitated by Quadrilateral Traffic in Transit Agreement" (QTTA). The QTTA was signed between China, Pakistan, Kazakhstan, and Kyrgyzstan in 2004. QTTA couldn't yield promising results because o9f long treacherous route and very poor road infrastructure, however, the APTTA can effectively compensate the deficiencies. Under this Agreement Pakistan enjoys the right of access to all countries contiguous to Afghanistan as follow:

i. Iran via Islam Qila and Zaranj

ii. Uzbekistan via Hairatan

iii. Tajikistan via Ali Khanum, Sher Khan Bandar

iv. Turkmenistan via Aqina and Torghundi:

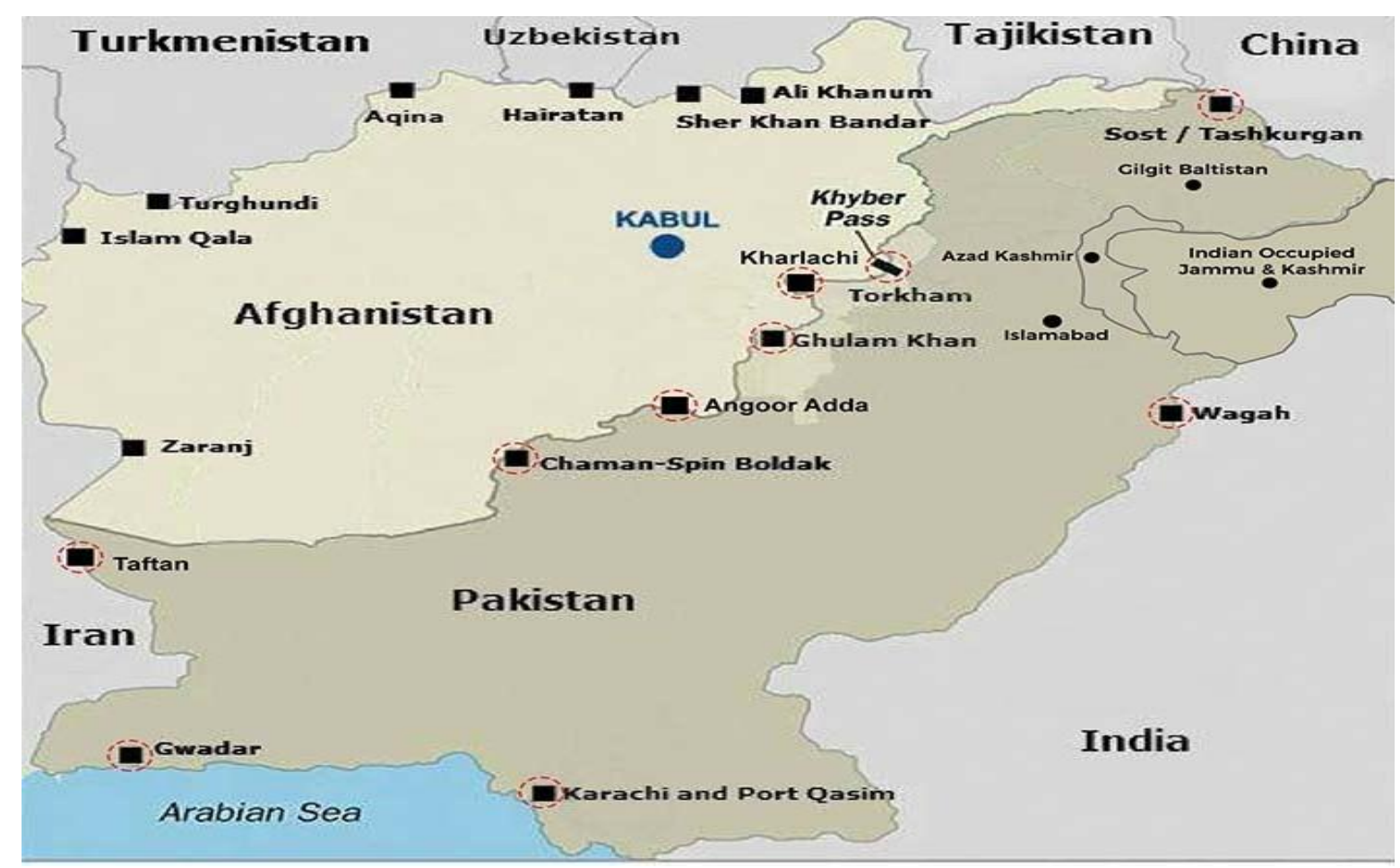




\section{Conclusion}

Regional peace passes through the promising economic integration between Pakistan and Afghanistan and success of this interlinking hinges upon intra-regional trade that is now seem viable with the introduction of APTTA-2010. The trade linkages with the Central Asian Republics (CARs) by Pakistan through Afghanistan has much room for growth and progress for the region as a whole. Currently, Pakistan's trade with the CARs is insignificant. Pakistan's exports to CARs via Afghanistan is a promising opportunity leading to increase in trade connectivity and socio- economic integration of the region. The landlocked Afghanistan seeks an opportunity to trade through Pakistan under the provision of GATT Article V, UN law of Seas 1981 and New York Convention-1965 that obligate to provide trade transit facilities to landlocked Afghanistan. APTTA-2010 opens trade horizons for both states by providing ten additional transit flight paths and eight corridors in Pakistan and Afghanistan respectively. According to APTTA both states must facilitate transportation of goods in their respective regions also provide free movement of transportation of goods on selected routes. Moreover, under this agreement each country provides transit routes by sea, air, land and train combine with provision of international standard services and infrastructure for transit trade. For road cargo Pak-Afghan governments are agreed to recognize and accept the transit trade carrier documents such as driving license, vehicles inspection certificate and registration also other technical documents like entry and exit permits etc. The study revealed that Afghan transit trade was decreased due to boarder closure over the years and Afghanistan seeks transit trade opportunities through Turkmenistan, Iran, Uzbekistan and Tajikistan as per mutually agreed transit trade agreements. Further, the study found that the decline in the volume of post-2014 trade is mainly because of withdrawal of international security forces from Afghanistan as well. However, the CPEC offers very glittering prospects for the regional trade connectivity through Pakistan-Afghanistan trade agreement which would be yielding unparalleled benefits for both countries

It is recommended that Pakistan need to review transit trade agreement with Afghanistan after operational of CPEC to take more benefits from long share boarder. This will not only strengthen Pakistan economy but also grant access to South and Central Asia. As the landlocked Afghanistan provide gateway opportunity to Pakistan for trading with Central Asia. It is suggested that Pakistan must seeks opportunity for trade with Bhutan and Nepal through Indian and facilitate accordingly as reciprocal of Afghan-India trade through Wagha. It is recommended that Pakistan need to build strong trade relation with Afghanistan to boost economy this may build trust among South Asian neighbors. It is recommended that Afghan must permit Pakistan to use land of Afghanistan for trade with Central Asia and beyond. Afghanistan and Pakistan need to adopt a more realistic approach towards each other's sensitivities. It is recommended that Pakistan must ensure to secure Afghan border crossing by terrorist that create trouble within Pakistan. For this purpose Pak-Afghan need combined efforts to address the issue. For good transit trade relation Afghanistan also needs to address Pakistan major concerns regard smuggling and terrorists/facilitators using Afghan land to sponsor terrorism inside Pakistan. It is also recommended that Pakistan use soft power and diplomatic channel to discus and address the issues accordingly. It is further recommended that both countries must ensure that their bilateral relation should not affect by any ties with other countries.

\section{References}

Abbasi, R. N. (2011). Presentation on Afghanistan - Pakistan Transit Trade Agreement 2010, Custom House Peshawar 2011.

Afghanistan (2010), Afghan Transit Trade at Pakistan's ports declines by 70pc. PAR, September 8, 2010, retrieved from http://custom.par.com.pk/news/afghan-transit-trade-at-pakistansports-declines-by70pc/, accessed 11/112015

Afzal, A. (2010, August 6). Afghan Pak Transit Trade Agreement- Facts and Irritants. Pak Tribune. Retrieved July 16, 2011, from http://paktribune.com/articles/Afghan-Pak-Transit-TradeAgreement---Facts-and-Irritants-230347.html.

APTTA (2010) Afghanistan Pakistan Transit Trade Agreement. Retrieved from: http://www.commerce.gov.pk/APTTA/APTTA.pdf

Baloch, Q. B., \& Niazi, A. H. K. (2008). Indian Encroachment in Afghanistan: A New Imperialism in the Making. The Dialogue, 3(1), 16-33

Baloch, Q. B. (2009). Pakistan's Trade Imbalance \& Melting down of Economy. Dialogue, 3(2), 148-167. 
Baloch, Q. B., \& Rehman, A. (2015). Regional integration of Pakistan tourism: Exploring prospects. Abasyn University Journal of Social Sciences, 8(2), 405-415.

Baloch, Q. B., Maher, S., \& Shah, S. Mohsin. A. (2020) Pakistan. Tourism revival through customer relationship in Swat, Dir \& Chitral triangle. 56(1): 25-50

Bokhari, S.W. (2015) Iran's Chabahar Port and the Strategic Turf Wars. 25/07/2015. Retrieved from http://viewsweek.com/southasia/pakistan/irans-chabahar-port-and-the-strategic-turf-wars/, accessed on 22/11/2015

Choudary, A. N. (2004). The Custom Act, 1969 with [Prevention Act, 1977 15th Edition], Lahore, Maktaba Jadeed Press.

FATA. (n.d.). FATA Development Authority, available at www.fatada.gov.pk [ last accessed on 12 October, 2011].

Federal Board of Revenue. (2011). Afghanistan- Pakistan Transit Trade Agreement 2010, Published by Ministry of Commerce 2011.

Gartenstein, D.-R. \& Vassefi, T. (2012). The Forgotten History of Afghanistan- Pakistan Relation. Yale Journal of International Affairs, 38-45.

Haider M., \& Irfan H., (2015). "Enemies of Afghanistan cannot be friends of Pakistan". The Dawn, May $12,2015$.

Haider, M. Z. (2015). Re-Examining Pak-Afghan Trade Arrangements. Business Record. Retrieved June 23, 2016, from my-library-promoting library advocacy.

Imtiaz Gul, "State of Pakistan-Afghanistan Relations," PILDAT, December 2012.

Irshad M., (2011). Terrorism in Pakistan: Causes \& Remedies. The Dialogue (Pakistan), 6(3), 224-241

Khawar H (2005), "Pakistan's Afghanistan Policy," Naval Post Graduate School, California.

Kiani, K. (2010). Pakistan-Afghan Accord on Transit Trade. Retrieved June 22, 2011, from http://www.dawn.com/wps/wcm/connect/dawn-content-library/ dawn/news/world/44-pak-afghanreach-consensus-over-transit-trade-fa-05.

Kiran, S. (2018). Determining the trade potential of trade between Pakistan and SAFTA countries using Gravity Model. City University Research Journal, 8(2).

Mahmoud, S. (2013). A Treaty to Learn From. The news International, p. 6.

Naqvi R. H., (2012). "Cultural History of Indian subcontinent; with special reference to Arts and Music".

Nuri, D. M. (2012, June 30). The Frontier Post. Retrieved September 28, 2012, from http://www.thefrontierpost.com/article/169128/.

Pakistan Observer. (2012, May 2). Retrieved April 17, 2012, from http://pakobserver.net/ detailnews.asp?id=153277.

Price, G. (2013). India's policy towards Afghanistan. Chatham House.

Qamar, F., \& Baloch, Q. B. (2017). Reviving Tourism through Entrepreneurial Capabilities in Swat, Dir \& Chitral Triangle in Post Operation Environment. Journal of Managerial Sciences, 11(2).

Raheem-ul-Haque. (2011). Pakistan, Afghanistan and US Relations: Implication and Future Direction. Centre for Public Policy and Governance.

Sarhadi, Z.-u.-H. (2013, January 23). Pak-Afghan: Joint Chamber of Commerce Conference. Daily, Ajj $(U r d u)$.

Siddique, A. Q. (2011, December 5). Pakistan to Resolve Afghan Trader's Problems. Retrieved February 7, 2012, from http://www.pajhwok.com/en/2010/11/29/afghan-pakistan-chamber-commerce-se

Syed Hussain, S. S. (2013, August 27). Redefining Strategic Dialogue. The News International, p. 4.

The Dawn, (2017, March 21). Pak-Afghan Border Crossings Opens after a Month of Closure. Dawn [https://www.dawn.com/news/1321930]

Umar S., (2009). "Pakistan's foreign Policy toward Afghanistan from 1947-2008," http://en.afghanistan.ru/doc/130.html last updated on May 16, 2009.

United Nation Publications. (n.d). Conventions and Statutes on Freedom of Transit, Available at http://treaties.un.org/doc/Publication/MTDSG/Volume\%20II/LON/PARTII-16.en.pdf [last accessed on 10 Nov, 2011]

Yousaf Tola, A. (2012). Pak-Afghan Transit Trade Agreement. Institute of Charted Accountant to Pakistan.

Yousufzai, (2017). "Pakistan-Afghanistan Relations: A Pakistani Narrative." 